\title{
A new species of Rhodinicola (Copepoda: Clausiidae), parasitic copepod of the shell-boring polychaete Polydora brevipalpa (Annelida: Spionidae) from the Sea of Japan
}

\author{
Tagea K.S. Björnberg1', Vasily I. Radashevsky²,3 \\ ${ }^{1}$ Centro de Biologia Marinha, Universidade de São Paulo, C.P. 71, 11600-000, São Sebastião, SP, \\ Brasil. \\ e-mail: cebimar@edu.usp.br \\ ${ }^{2}$ A.V. Zhirmunsky Institute of Marine Biology, Far Eastern Branch of the Russian Academy of \\ Sciences, 17 Palchevsky Street, Vladivostok 690041, Russia. \\ e-mail: radashevsky@gmail.com \\ ${ }^{3}$ Far Eastern Federal University, 8 Sukhanov Street, Vladivostok 690091, Russia.
}

ABSTRACT: The new clausiid copepod Rhodinicola polydorae sp.n. is an ectoparasite of a spionid polychaete Polydora brevipalpa Zachs, 1933 in Peter the Great Bay of the Sea of Japan (EastSea). The host polychaete bores into shells of the Yesso scallop Mizuhopecten yessoensis (Jay, 1857). This is the first report of annelidicolous copepods from the Sea of Japan (East Sea) and the first description of a copepod parasitic on spionid polychaetes from Asia.

KEY WORDS: clausiid copepod, annelidicolous parasite, adult morphology.

\section{Новый вид копеподы Rhodinicola (Copepoda: Clausiidae), паразитирующей на сверлящей полихете Polydora brevipalpa (Annelida: Spionidae) в Японском море}

\author{
Т.К.С. Бьёрнберг ${ }^{1}$, В.И. Радашевский ${ }^{2,3}$ \\ ${ }^{1}$ Centro de Biologia Marinha, Universidade de São Paulo, C.P. 71, 11600-000, São Sebastião, SP, \\ Brasil. \\ e-mail:cebimar@edu.usp.br \\ ${ }^{2}$ A.V. Zhirmunsky Institute of Marine Biology, Far Eastern Branch of the Russian Academy of \\ Sciences, 17 Palchevsky Street, Vladivostok 690041, Russia. \\ e-mail: radashevsky@gmail.com \\ ${ }^{3}$ Far Eastern Federal University, 8 Sukhanov Street, Vladivostok 690091, Russia.
}

РЕЗЮМЕ: Новый вид копепод клаузиид Rhodinicola polydorae sp.n. паразитирует на полихете спиониде Polydora brevipalpa Zachs, 1933 в заливе Петра Великого Японского моря. Полихета-хозяин - сверлильщик раковин приморского гребешка Mizuhopecten yessoensis (Jay, 1857). Это первое сообщение о копеподах, паразитирующих на полихетах в Японском море, и первое описание копепод, паразитирующих на полихетах спионидах в прибрежных водах Азии.

КЛЮЧЕВЫЕ СЛОВА: копеподЫ, полихеты, паразитизм, морфология. 


\section{Introduction}

Copepods exhibit diverse modes of life; they are primarily free-living but have evolved symbiotic relationships with many marine organisms. They are known to utilize as hosts virtually every metazoan phylum (Boxshall, Halsey, 2004; Gotto, 2004). More than 120 species of Copepoda are associated with annelids and most of these are either external or internal parasites of polychaetes (Humes, 1994; Boxshall, Halsey, 2004; Gotto, 2004). The annelid associates, collectively called annelidicolous copepods, have been placed in 17 families of copepods: Bradophilidae Marchenkov, 2002, Clausidiidae Embleton, 1901, Clausiidae Giesbrecht, 1895, Entobiidae Ho, 1984, Eunicicolidae Sars, 1918, Gastrodelphyidae List, 1889, Herpyllobiidae Hansen, 1892, Lichomolgidae Kossmann, 1877, Saccopsidae Lützen, 1964, Monstrillidae Dana, 1849, Nereicolidae Claus, 1875, Phyllodicolidae Delamare-Deboutteville et Laubier, 1961, Pseudanthessiidae Humes et Stock, 1972, Sabelliphilidae Gurney, 1927, Serpulidicolidae Stock, 1979, Spiophanicolidae Ho, 1984, and Xenocoelomatidae Bresciani et Lützen, 1966. Besides annelid symbionts, these families also contain free-living members and/or associates of other invertebrates, thus symbiotic relationships with polychaetes might have evolved independently from various copepod ancestors. Annelidicolous copepods are usually associated with a specific host but some occur on more than one host species (see Gotto, 2004: Host-Associate List). Polychaetes hosting copepods belong to families Acoetidae Kinberg, 1856 (including Polyodontidae Augener, 1918), Ampharetidae Malmgren, 1866, Amphinomidae Savigny in Lamarck, 1818, Capitellidae Grube, 1862, Eunicidae Berthold, 1827, Flabelligeridae de Saint-Joseph, 1894, Maldanidae Malmgren, 1867, Nereididae Johnston, 1865, Opheliidae Malmgren, 1867, Phyllodocidae Örsted, 1843, Polynoidae Malmgren, 1867, Sabellidae Latreille, 1825 (including Serpulidae Rafinesque, 1815), Siboglinidae Caullery, 1914, Spionidae Grube, 1850, Syllidae Grube, 1850, and Terebel- lidae Malmgren, 1867 (including Trichobranchidae Malmgren, 1866).

The copepod family Clausiidae includes mainly ectoparasites of maldanid and spionid polychaetes living in diverse habitats worldwide. Ho and Kim (2003) provided the first phylogenetic analysis of 20 species of Clausiidae based on 28 morphological characters, all from the thoracic legs. The resulting cladograms suggested inclusive relationships among six groups of species, Pontoclausia(Likroclausia (Rhodinicola (Mesnilia (Clausia (Pseudoclausia))))) which did not correspond exactly to the genera recognized at that time (Ho, Kim, 2003: Fig. 8). Based on these results, the authors established a new genus Likroclausia Ho et Kim, 2003 and suggested that the Clausia Claparède, 1863, Mesnilia Canu, 1898, Pontoclausia Bãcescu et Por, 1959, Pseudoclausia Bocquet et Stock, 1960, and Rhodinicola Levinsen, 1878 should be treated as valid genera in the Clausiidae, while the taxonomical status of the genera Indoclausia Sebastian \& Pillai, 1974, Megaclausia O'Reilly, 1995, Pherma Wilson C.B., 1923, and Seridium Giesbrecht, 1895 remains uncertain. Since then, a new genus Spionicola was established by Björnberg and Radashevsky (2009) to accommodate a new species from Brazil, S. mystaceus Björnberg et Radashevsky, 2009.

In the Asian Pacific, nine species of copepods from the families Clausidiidae, Clausiidae and Sabelliphilidae have been described as ectoparasitic on the adult polychaetes from the families Arenicolidae, Capitellidae, Nereididae, Sabellidae and Terebellidae from the coastal waters of the Korea Straight and the Yellow Sea in Korea (Ho, Kim, 1990, 2003; Kim, Ho, 1992; Kim, 1998, 2000,2001a,b,c). Unidentified copepods endoparasitic in the adults of Polydorella Augener, 1914 (Spionidae) were reported from the South China Sea, Vietnam (Radashevsky, 1996) and Philippines (Williams, 2004).

During a study of the spionid polychaetes in the Sea of Japan (East Sea), one pair of endoparasitic copepods were found in adult Dipolydora trilobata Radashevsky, 1993 that was boring into shells of the Pacific oyster Crassostrea 


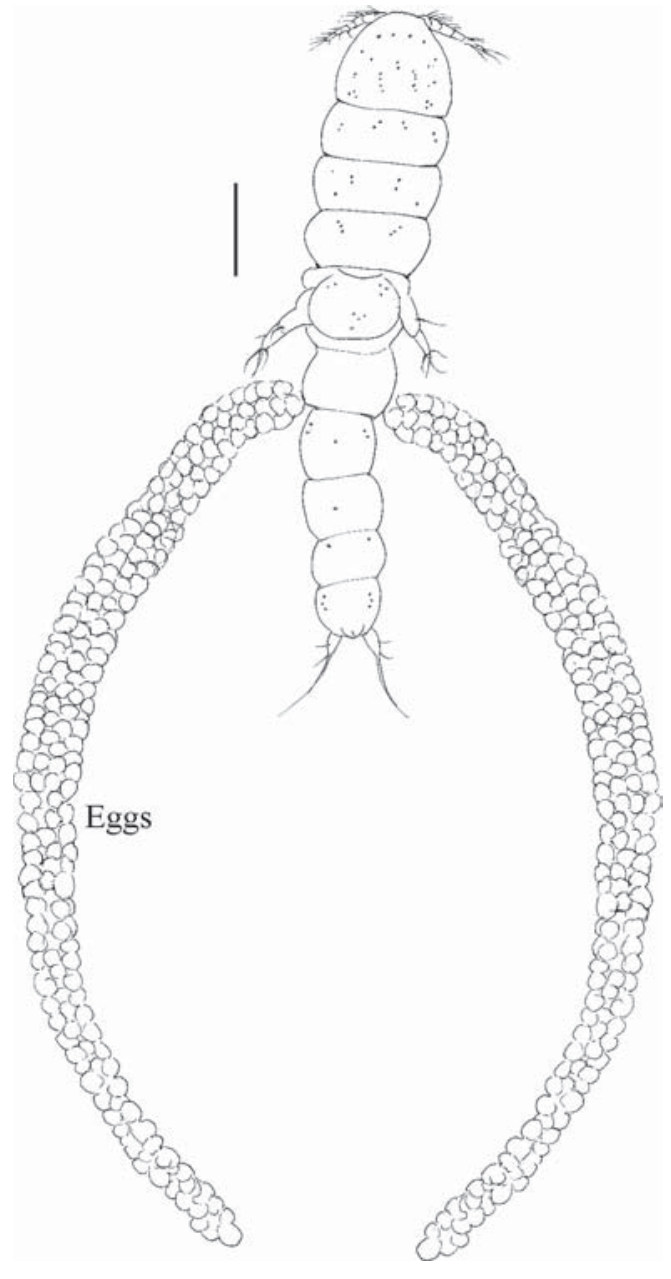

Fig. 1. Rhodinicola polydorae sp.n. Female morphology. Dorsal view, with egg strings (Eggs). Scale bar: $0.5 \mathrm{~mm}$.

Рис. 1. Rhodinicola polydorae sp.n. Самка. Вид со спинной стороны, с кладкой яиц (Eggs). Масштаб: 0,5 мм

gigas Thunberg, 1793, one pair of ectoparasitic copepods was found on adult Boccardiella hamata (Webster, 1879) boring into shells of the Yesso scallop Mizuhopecten yessoensis (Jay, 1857), and numerous ectoparasitic copepods of another species were found on adults of Polydora brevipalpa Zachs, 1933, obligate borer of the Yesso scallop M. yessoensis (see Radashevsky, 1993). The morphology of the latter copepods is described and illustrated in the present paper.
This is the first report of annelidicolous copepods in the Sea of Japan (East Sea) and the first description of a copepod parasitic on spionid polychaetes in Asia (see Table 1).

\section{Material and methods}

Field collections were made in Vostok Bay (part of the larger Peter the Great Bay) of the Sea of Japan (East Sea) intertidally and in shallow water using SCUBA from 2000 through 2011. Samples were processed at the Vostok Marine Biological Station of the Institute of Marine Biology. Sediment samples were sieved with $0.5 \mathrm{~mm}$ mesh sieve; mollusc shells were broken with hammer and pliers. Adults of more than 30 species of spionid polychaetes living in temporary mucous and permanent silty tubes, boring into sponges and shells of various mollusks were examined alive with a microscope to separate parasitic copepods. Numerous ectoparasitic copepods found on Polydora brevipalpa boring in shells of the Yesso scallop M. yessoensis were detached from the worms, fixed in $10 \%$ formalin solution, rinsed in fresh water, and transferred to $70 \%$ ethanol. For examination, entire copepods and divided parts were cleared in lactic acid and mounted on slides with glycerin. Drawings were made using a camera lucida; photographs were taken using a digital camera at the Center of Marine Biology, University of São Paulo. Fixed specimens were deposited at the Museum of the Institute of Marine Biology, Vladivostok, Russia (MIMB) and the Zoological Museum of the University of São Paulo, São Paulo, Brazil (MZUSP).

\section{Results}

Copepoda Mílne-Edwards, 1840

Clausiidae Giesbrecht, 1895

Rhodinicola Levinsen, 1878

\section{Rhodinicola polydorae sp.n.}

Figs 1-6.

MATERIAL. RUSSIA, Sea of Japan, Vostok Bay of Peter the Great Bay: $42^{\circ} 53.6^{\prime} \mathrm{N}, 132^{\circ} 44^{\prime} \mathrm{E}$, from spionid polychaete Polydora brevipalpa boring in shells of Yesso 
Table 1. List of spionid polychaetes hosting parasitic copepods. Таблица 1. Список полихет спионид, на которых обнаружены паразитические копеподы.

\begin{tabular}{|c|c|c|c|c|}
\hline Host Spionidae & Parasitic Copepoda & Association & Locality & Reference \\
\hline $\begin{array}{l}\text { Boccardiella hamata } \\
\text { (Webster, 1879) }\end{array}$ & Copepoda & ectoparasite & $\begin{array}{l}\text { Sea of Japan, } \\
\text { Russia }\end{array}$ & present study \\
\hline $\begin{array}{l}\text { Dipolydora armata } \\
\text { (Langerhans, 1880) }\end{array}$ & $\begin{array}{l}\text { Spionicola mystaceus } \\
\text { Björnberg \& } \\
\text { Radashevsky, } 2009 \\
\text { (Clausiidae) }\end{array}$ & ectoparasite & $\begin{array}{l}\text { São Paulo, } \\
\text { Brazil }\end{array}$ & $\begin{array}{l}\text { Björnberg \& } \\
\text { Radashevsky, } \\
2009\end{array}$ \\
\hline $\begin{array}{l}\text { Dipolydora flava } \\
\text { (Claparède, 1870) }\end{array}$ & $\begin{array}{l}\text { Mesnilia cluthae (T. \& A. } \\
\text { Scott, 1896); Mesnilia } \\
\text { martinensis Canu, } 1898 \\
\text { (Clausiidae) }\end{array}$ & ectoparasite & $\begin{array}{l}\text { La Manche, } \\
\text { France }\end{array}$ & $\begin{array}{l}\text { Bocquet \& } \\
\text { Stock, } 1959\end{array}$ \\
\hline $\begin{array}{l}\text { Dipolydora trilobata } \\
\text { Radashevsky, } 1993\end{array}$ & Copepoda & endoparasite & $\begin{array}{l}\text { Sea of Japan, } \\
\text { Russia }\end{array}$ & present study \\
\hline $\begin{array}{l}\text { Polydora brevipalpa } \\
\text { Zachs, } 1933\end{array}$ & $\begin{array}{l}\text { Rhodinicola polydorae } \\
\text { sp.n. (Clausiidae) }\end{array}$ & ectoparasite & $\begin{array}{l}\text { Sea of Japan, } \\
\text { Russia }\end{array}$ & present study \\
\hline $\begin{array}{l}\text { Polydora ciliata } \\
\text { (Johnston, 1838) }\end{array}$ & $\begin{array}{l}\text { Mesnilia cluthae (T. \& A. } \\
\text { Scott, 1896) (Clausiidae) }\end{array}$ & ectoparasite & $\begin{array}{l}\text { La Manche, } \\
\text { France }\end{array}$ & $\begin{array}{l}\text { Bocquet \& } \\
\text { Stock, } 1959 \\
\end{array}$ \\
\hline $\begin{array}{l}\text { Polydorella dawydoffi } \\
\text { Radashevsky, } 1996\end{array}$ & Copepoda & endoparasite & $\begin{array}{l}\text { South China } \\
\text { Sea, } \\
\text { Vietnam } \\
\end{array}$ & $\begin{array}{l}\text { Radashevsky, } \\
1996\end{array}$ \\
\hline $\begin{array}{l}\text { Polydorella stolonifera } \\
\text { (Blake \& Kudenov, } \\
\text { 1978) }\end{array}$ & Copepoda & endoparasite & Philippines & $\begin{array}{l}\text { Williams, } \\
2004\end{array}$ \\
\hline $\begin{array}{l}\text { Spiophanes } \\
\text { berkeleyorum Pettibone, } \\
1962\end{array}$ & $\begin{array}{l}\text { Spiophanicola spinulosus } \\
\text { Ho, } 1984 \\
\text { (Spiophanicolidae) }\end{array}$ & ectoparasite & $\begin{array}{l}\text { California, } \\
\text { USA }\end{array}$ & Но, 1984 \\
\hline $\begin{array}{l}\text { Spiophanes kroyeri } \\
\text { Grube, } 1860\end{array}$ & $\begin{array}{l}\text { Spiophanicola spinulosus } \\
\text { Ho, } 1984 \\
\text { (Spiophanicolidae) }\end{array}$ & ectoparasite & $\begin{array}{l}\text { California, } \\
\text { USA }\end{array}$ & Но, 1984 \\
\hline $\begin{array}{l}\text { Spiophanes } \\
\text { missionensis Hartman, } \\
1941\end{array}$ & $\begin{array}{l}\text { Spiophanicola spinulosus } \\
\text { Ho, } 1984 \\
\text { (Spiophanicolidae) }\end{array}$ & ectoparasite & $\begin{array}{l}\text { California, } \\
\text { USA }\end{array}$ & Нo, 1984 \\
\hline
\end{tabular}

scallop Mizuhopecten yessoensis, 3-10 m depth, coll. V.I. Radashevsky, 8 Apr 2009: MIMB 26496 (holotype: female), MZUSP 24448 (allotype: male), MIMB 26498 (1 paratype: female), MZUSP 24447 (2 paratypes: females); 6 Oct 2007: MIMB 26497 (paratype: female with egg strings); 12 Dec 2010: MIMB 26499 (19 paratypes: 17 females + 2 males); 27 Apr 2011: MIMB 26500 (19 paratypes: 15 females with egg strings +4 males).

FEMALES (Figs. 1-4, 6A, B). Body elongate, 10 -segmented, broader anteriorly, $0.53-$ $0.82 \mathrm{~mm}$ wide on widest cephalosome and second somite, $1.9-3.5 \mathrm{~mm}$ long from anterior margin of rostrum to end of caudal rami (setae excluded). Cephalothorax subtriangular. Pedigerous somites short; each about twice wider than long. Urosomites each about 1.5 times wider than long. Caudal rami twice longer than wide, with four short and one long terminal setae distinctly longer than caudal ramus. Pores, each with a sensillum, scattered over dorsal part of body. Anal pseudoperculum small, rounded posteriorly.

Rostrum (Figs. 2B, 3A) small, dorsally weakly defined, wider than long. Antennule (Fig. 2C) 6-segmented, tapering gradually, shorter than cephalosome, setal formula: $5,7,10,5,2+$ aesthetask, 8 with setiform aesthetascs on the second, third, fifth and sixth segments. All setae naked. Antenna (Fig. 2D) 3-segmented, coxa with wide patch of spinules and one distal seta; second and third segments with spinules; third segment also bearing lateral row of setules, two inner short setae, two long outer setae and row of four terminal claws increasing in length from 


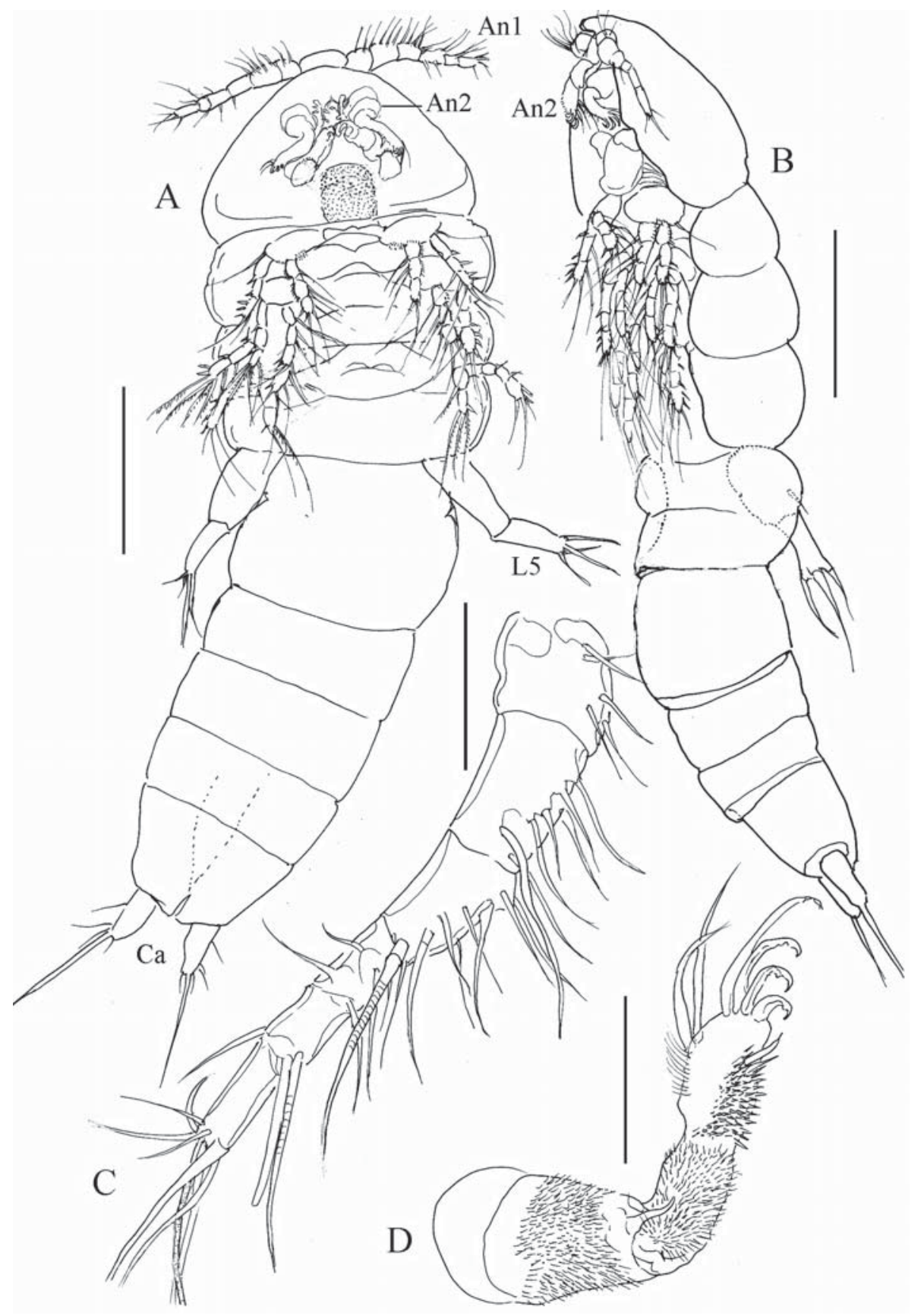

Fig. 2. Rhodinicola polydorae sp.n. Female morphology.

A - ventral view, right third leg omitted, showing antennule (An1), antenna (An2), caudal rami (Ca), and Leg V (L5); B - left lateral view; C - antennule; D - antenna. Scale bars: A, B - $0.5 \mathrm{~mm}, \mathrm{C}, \mathrm{D}-0.1 \mathrm{~mm}$.

Рис. 2. Rhodinicola polydorae sp.n. Самка.

A - вид с брюшной стороны, третья правая конечность не показана; антеннула (An1), антенна (An2), хвостовые придатки (Ca), ножка V (L5); В — вид слева; C — антеннула; D — антенна. Масштаб: A, B — 0,5 мм, C, D 0,1 мм. 


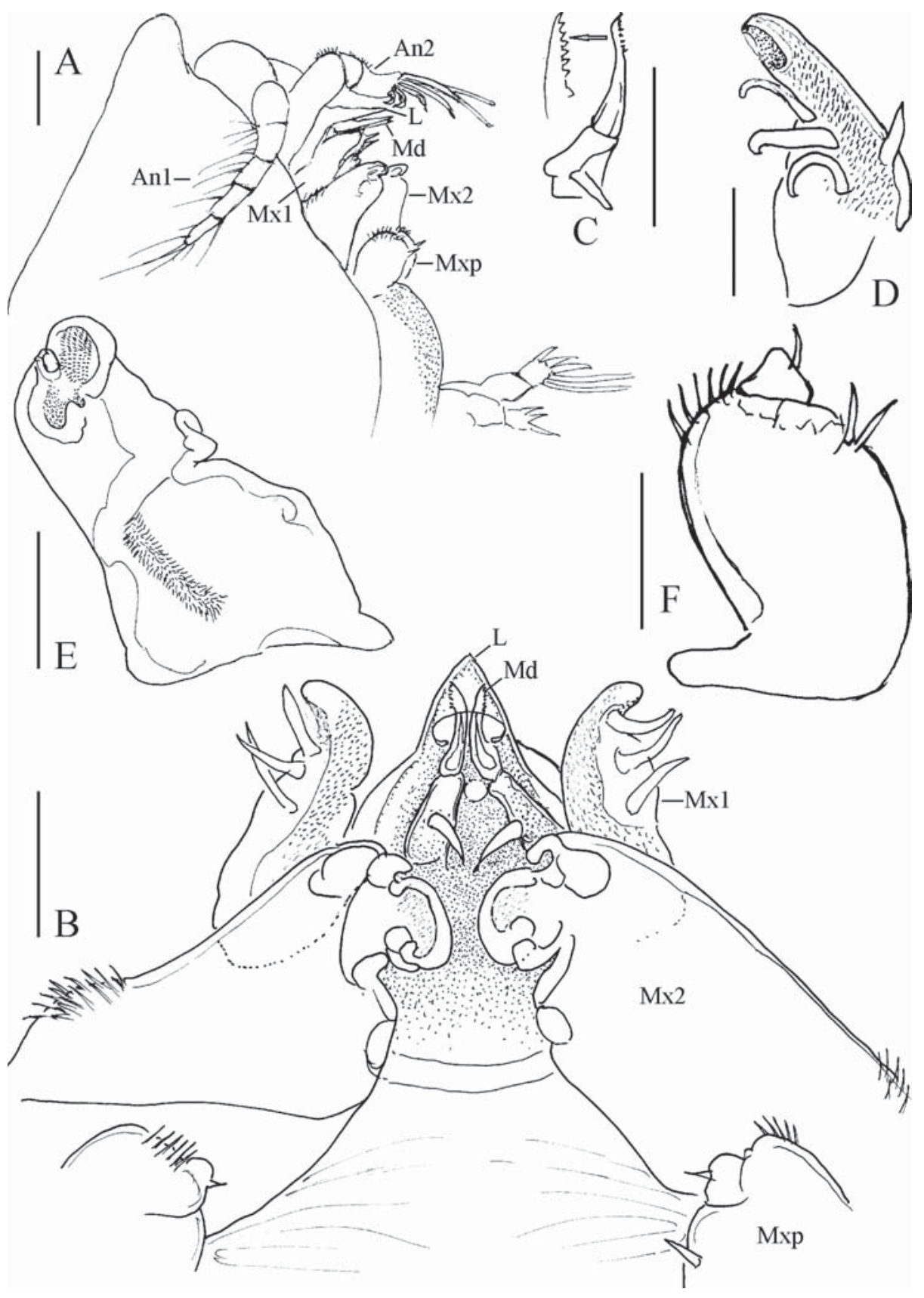

Fig. 3. Rhodinicola polydorae sp.n. Female morphology.

A - right lateral view of mouth region, showing antennule (An1), antenna (An2), labrum (L), mandible (Md), maxillule (Mx1), maxilla (Mx2), and maxilliped (Mxp); B - ventral view of mouth region; C - mandible; D - maxillule; E maxilla; F - maxilliped. Scale bars: A $-0.1 \mathrm{~mm}, \mathrm{~B}-\mathrm{F}-0.05 \mathrm{~mm}$.

Рис. 3. Rhodinicola polydorae sp.n. Самка.

A — ротовая область, вид справа; антеннула (An1), антенна (An2), верхняя губа (L), мандибула (Md), максиллула (Mx1), максилла (Мх2), максиллипед (Мхр); В — ротовая область, вид с брюшной стороны; С — мандибула; D максиллула; Е — максилла; F — максиллипед. Масштаб: А — 0,1 мм, B-F — 0,05 мм. 


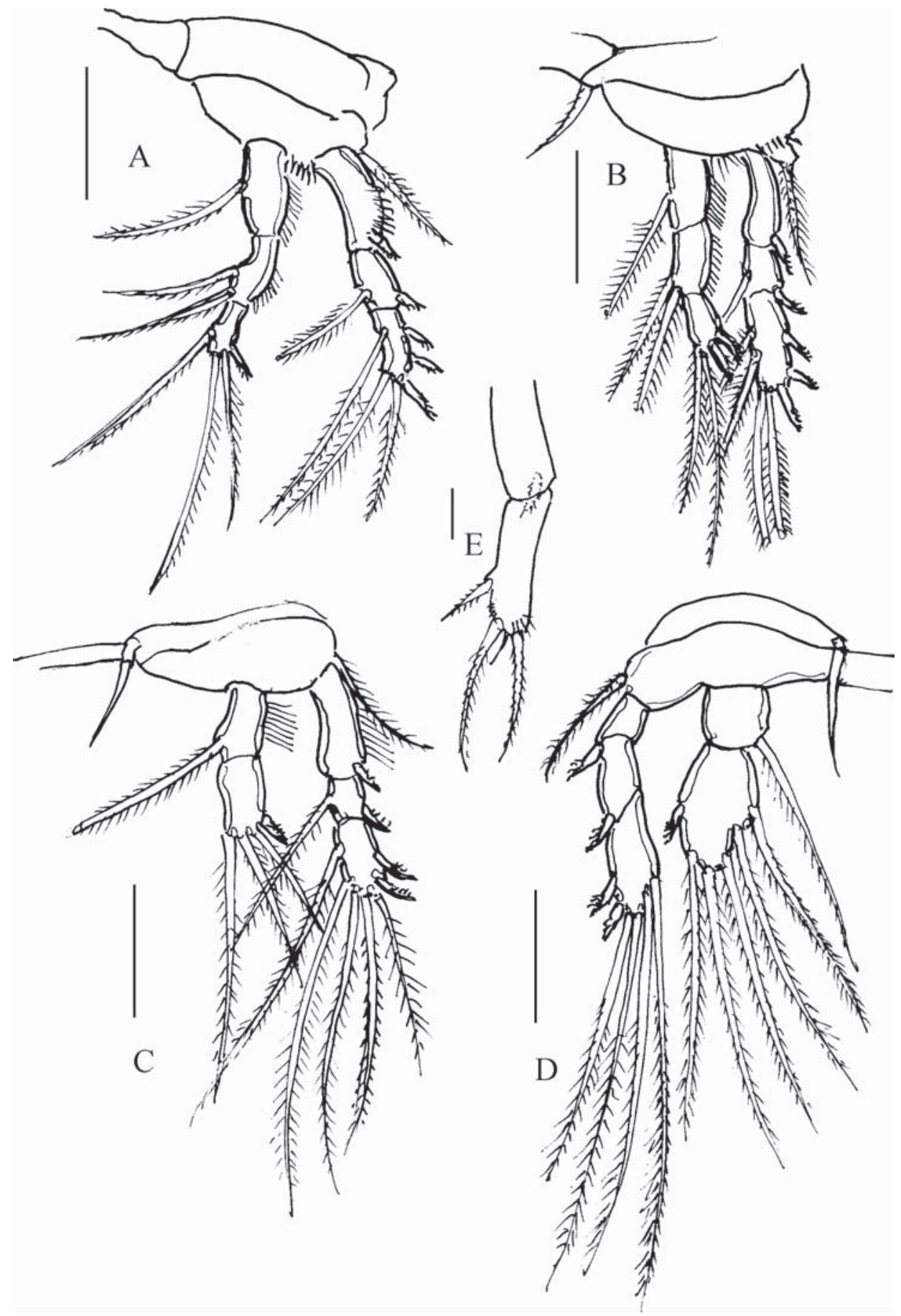

Fig. 4. Rhodinicola polydorae sp.n. Female morphology.

A - Leg I; B - Leg II; C - Leg III; D - Leg IV; E - Leg V. Scale bars: A-E - $0.1 \mathrm{~mm}$.

Рис. 4. Rhodinicola polydorae sp.n. Самка.

A — ножка I; B - ножка II; C — ножка III; D — ножка IV; E — ножка V. Масштаб: A-E — 0,1 мм. 
inner towards outer side. Labrum transparent, triangular, pointed, hardly visible (Fig. 3A, B), covering distal part of mandible. Mandible (Fig. 3C) with one distal and one lateral spine; distal spine armed with several teeth distally. Maxillule (Fig. 3D) small, tapering slightly distally, bearing three outer and one inner setae with long patch of minute spinules. Maxilla (Fig. 3E) largest oral appendage, 2-segmented, coneshaped, with outer strip of setules and distal cushion-like pad bearing setules. Maxilliped (Fig. 3F) small, oval and 2-segmented; proximal segment with patch of spinules distally and two larger medial spines; subtriangular endopod tipped by one small spine.

Legs 1 to 4 (Fig. 4A-D) biramous; first and second legs with 3-segmented exopods and endopods; third and fourth legs with 3-segmented exopods and 2-segmented endopods. Marginal rows of strong spinules present on first exopodal segment and first two endopodal segments of leg 1. Formula of spines and setae on these legs as follows:

\begin{tabular}{|l|c|c|c|c|}
\hline & Coxa & Basis & Exopod & Endopod \\
\hline Leg 1: & 0 & 1 & I, $0-$ I, 1-III, 1,2 & $01-0-$ I, 2, 1 \\
\hline Leg 2: & 1 & 1 & I, $0-$ I, 1 - III, 2, 2 & $01-02-$ I, I, 2 \\
\hline Leg 3: & 1 & 1 & I, $0-$ I, 1 - II, 2, 3 & $01-$ I, 2, 1 \\
\hline Leg 4: & 1 & 1 & I, $0-$ I, $0-$ II, 2, 2 & $01-$ I, 2, 3 \\
\hline
\end{tabular}

Leg 5 uniramous, 2-segmented, large and laterally projecting (Fig. 4E): proximal segment with one dorsal seta; distal segment with one lateral spine, two terminal long setae and one thin small seta.

Leg 6 represented by one minute seta on egg attachment area.

MALES (Fig. 5). Slender and about half as small as females, $0.34-0.44 \mathrm{~mm}$ wide and $1.3-$ $1.7 \mathrm{~mm}$ long. Body with 10 somite complexes. Pores, each with sensillum, scattered over dorsum (Fig. 5A). Appendages similar to those in females, except maxilliped being more powerful (Fig. 5D), with one strong terminal hook, one large, tapering medial process, two setae and patches of setules on second segment. Legs 1-5 similar to those in females, except distal spine of leg 1 endopod being stronger than in females. Leg 6 represented by one lateral seta on each distal margin of genital somite.
BIOLOGY. Adults of R. polydorae sp.n. are ectoparasites on adult spionid polychaetes $P$. brevipalpa, living attached along the dorsum of the middle part of the worm's body. Host polychaetes attain $70 \mathrm{~mm}$ long and $2 \mathrm{~mm}$ wide for 170 chaetigers; constant beating of cilia on the branchiae and dorsum provides ventilation inside the worm burrow and brings oxygen to the parasitic copepods. The copepods grasp the host worms with antennal hooks and pierce the body wall with mandibles. One host spionid is usually infested by one pair of copepods, female and smaller male, within close proximity to each other. Observations indicate that once disturbed, the copepods easily detach themselves from the host and swim away.

Some females had two long external strings of eggs attached to the genital sixth somite (Figs. 1, 6A), and most females contained numerous oocytes in the coelomic cavity (Fig. 6A, B). Eggs in the strings were about $50 \mu \mathrm{m}$ in diameter. The larval development is unknown but possibly partly occurs inside the worm burrow in the shell.

Up to eight species of spionid polychaetes bore into shells of the Yesso scallop M. yessoensis in north-western part of the Sea of Japan (see Radashevsky, 1993). Although boring spionids often co-occur on one scallop shell, $R$. polydorae sp.n. was found as a common associate of only one of them, P. brevipalpa.

ETYMOLOGY. The species name, polydorae refers to the host spionid polychaete, Polydora brevipalpa. In Greek mythology, Polydo$r a$ is one of 3000 Oceanides, daughters of the God of the river Oceanus and Tethys, the Titan goddess of the sources fresh water which nourished the earth, a daughter of Uranus and Gaea.

\section{Discussion}

A comprehensive hypothesis about relationships of parasitic copepods has not yet been developed, and placing annelidicolous species into genera and even families is often still problematic. According to the cladistic analysis by Ho and Kim (2003), clausiid copepods with a posteromedial element (spine or seta) on the 

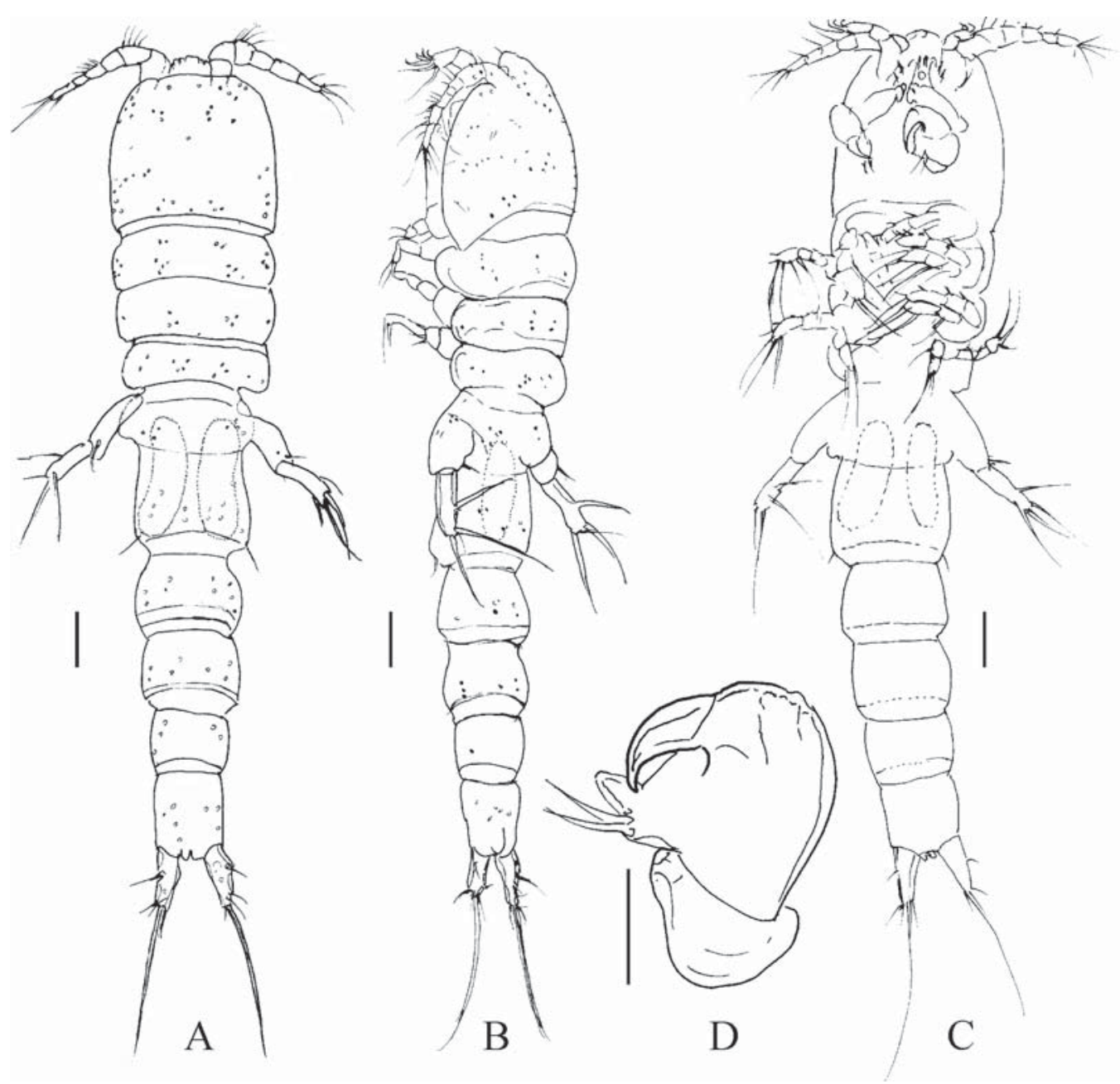

Fig. 5. Rhodinicola polydorae sp.n. Male morphology.

A - dorsal view; B - left lateral view; C - ventral view; D - maxilliped. Scale bars: A-C - $0.1 \mathrm{~mm}, \mathrm{D}-0.05 \mathrm{~mm}$. Рис. 5. Rhodinicola polydorae sp.n. Самец.

A — вид со спинной стороны; В - вид сбоку; C — вид с брюшной стороны; D — максиллипед. Масштаб: А$\mathrm{C}-0,1$ мм, D-0,05 мм.

basis of leg 1 formed two groups, Pontoclausia and Likroclausia, while the rest of clausiids share a derived synapomorphy, the absence of this element. This analysis also suggested that clausiids with biramous legs 1 to 4 formed three groups, Pontoclausia, Likroclausia, and Rhodinicola, while other clausiids had uniramous thoracic legs with endopods lacking. Pontoclausia contained the most primitive clausiids carrying a spine on the posteromedial surface of the basis of leg 1; Likroclausia was unique in the possession of a naked seta on the posteromedial surface of the basis of leg 1, and also the antler-like projections on the pedigers 2 through 4 and the conversion of leg 1 endopod into a prehensile structure; while Rhodinicola members shared the absence of an element on the posteromedial surface of the basis of leg 1 , and the presence of 3 -segmented endopods on thoracic legs 3 and 4 (Ho, Kim, 2003). Despite their not sister but 

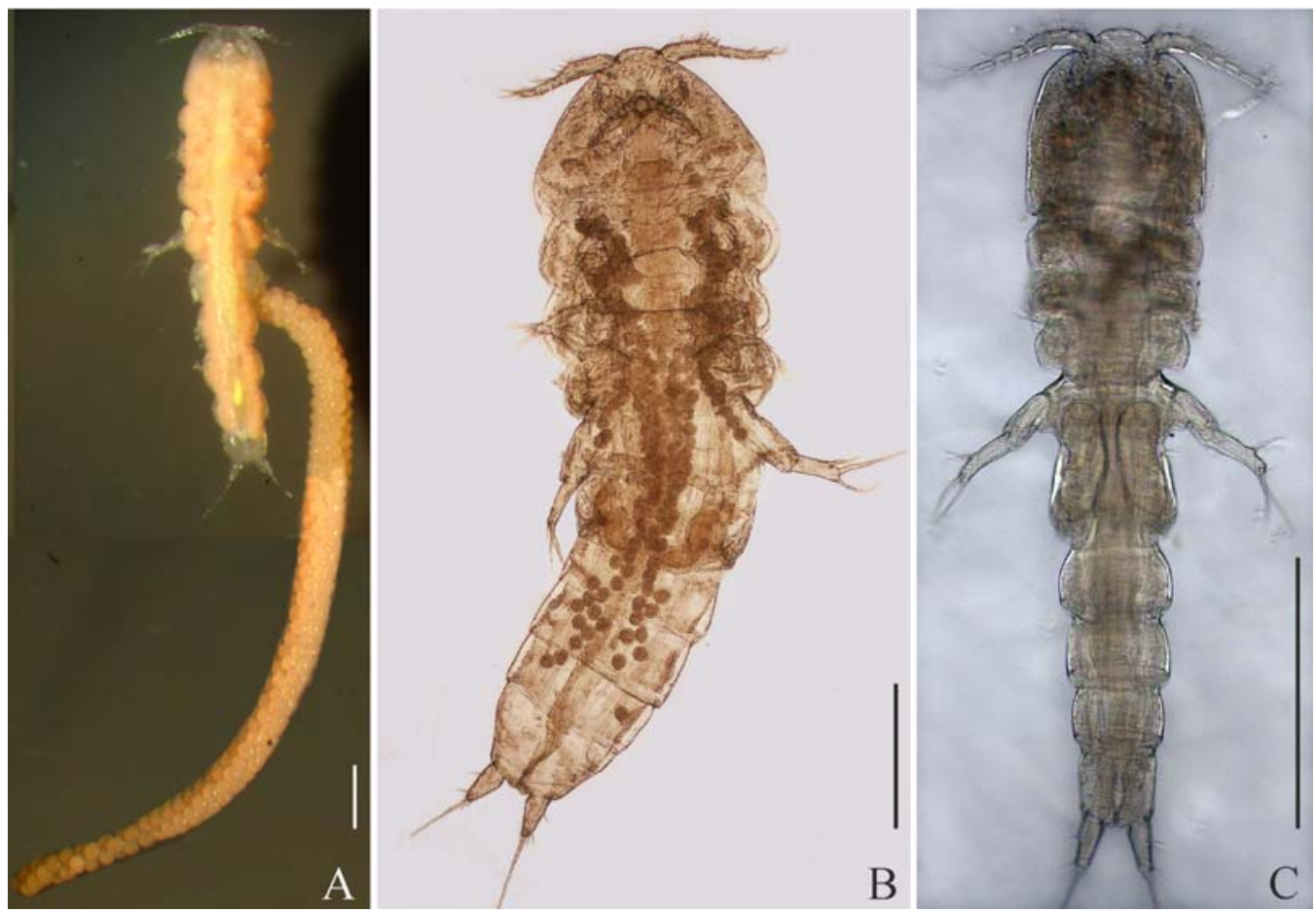

Fig. 6 Rhodinicola polydorae sp.n. Adult morphology.

A — female with left egg string, right egg string missing, ventral view; B — female, dorsal view; C - male, dorsal view. A-C - fixed specimens. Scale bars: A-C $-0.5 \mathrm{~mm}$.

Рис. 6. Rhodinicola polydorae sp.n.

А — самка с левой кладкой яиц, правая кладка яиц отсутствует, вид с брюшной стороны; В — самка, вид со спинной стороны; C - самец, вид со спинной стороны. A-C - фиксированные особи. Масштаб: $\mathrm{A}-\mathrm{C}-0,5$ мм.

inclusive relationships, these groups were considered as valid genera by Ho and Kim (2003).

The clausiid copepods described herein have all thoracic legs biramous and no seta or spine on the posteromedial surface of the basis of leg 1. According to the analysis by Ho and Kim (2003), they should therefore be referred to Rhodinicola. In a comprehensive review of copepods, Boxshall and Halsey (2004) stated that they followed the scheme by Ho and Kim (2003), and included the species mentioned by Ho and Kim (2003) into Rhodinicola. However, in the identification key for the genera of Clausiidae they did not consider the basal posteromedial element on leg 1. Consequently, according to Boxshall and Halsey's (2004) key for the genera, the copepods described herein should be referred to Pontoclausia. In the present paper, we follow Ho and Kim (2003) and refer the new species to Rhodinicola.

Adults of $R$. polydorae sp.n. differ from those of other species of Rhodinicola in having 2-segmented instead of 3-segmented endopods on legs 3 and 4 that were considered by Ho and $\operatorname{Kim}(2003)$ as plesiomorphic for clausiids. It is remarkable that adults of other species of Rhodinicola, $R$. elongata Levinsen, $1878, R$. gibbosa Bresciani, 1964, R. rugosa (Giesbrecht, 1897), and $R$. thomassini Laubier, 1970 are all parasites of maldanid polychaetes (Maldanidae; see Boxshall, Halsey, 2004) whereas adults of $R$. polydorae sp.n. are parasites of a spionid polychaete (Spionidae).

Rhodinicola polydorae sp.n. is most similar to R. laticauda Ho et Kim, 2003 from the Yellow Sea, Korea. The latter species was described based on single female obtained from washings of an unidentified polychaete collect- 
ed on intertidal sandstone (Ho, Kim, 2003). Besides the presence of 2-segmented endopods on legs 3 and 4, R. polydorae sp.n. differs from $R$. laticauda in having a transparent pointed labrum. These two species differ from $R$. gibbo$s a$ and $R$. elongata in lacking papilliform spines on the basal segment of the antennule, in having a subterminal spine on the mandible, a thumblike spinulose projection on the maxillule, a much reduced maxilliped in the female and a smaller caudal ramus in comparison with the anal somite.

\section{Acknowledgements}

Our sincere thanks to Alvaro Esteves Migotto for photographing the copepods, providing generous support and working conditions in the Center of Marine Biology of the University of São Paulo, Brazil, Virgínia Castilho and Wagney Messias da Costa for help with drawings and literature, and Chad Walter for providing literature and reviewing the text. We are also very thankful to Ju-shey Ho and an anonymous reviewer for providing helpful comments and editing the manuscript. Financial support was provided by the Russian Foundation for Basic Research (RFBR Project \# 09-04-01235), the Government of the Russian Federation (Project 11.G34.31.0010), the Far East Branch of the Russian Academy of Sciences (FEB RAS Project 09-III-A-06-209), and the Coordenação de Aperfeiçoamento de Pessoal de Nível Superior (CAPES), do Ministério da Educação do Brasil through the Universidade Federal do Rio de Janeiro (Edital PVE, CGCI nº 014/2008).

\section{References}

Björnberg T.K.S., Radashevsky V.I. 2009. A new genus and a new species of Clausiidae (Crustacea, Copepoda) parasitic on Dipolydora armata (Polychaeta, Spionidae) in Brazil // Papéis Avulsos de Zoologia. Vol.49. No.20. P.249-256.

Bocquet C., Stock J.H. 1959. Copépodes parasites d'invertébrés des côtes de la Manche. V. Redescription de Mesnilia cluthae (Th. et A. Scott) (Copépode Cyclopoïde, familie des Clausiidae) // Archives de Zoologie Expérimentale et Générale. Vol.97. No.1. P.1-18.
Boxshall G.A., Halsey S.H. 2004. An introduction to copepod diversity. (The Ray Society Series, Vol.166). London, UK: Ray Society. 966 p.

Gotto V. 2004. Commensal and parasitic copepods associated with marine invertebrates // Synopsis of the British Fauna (New Series). J.H. Crothers and P.J. Hayward (eds.). Vol.46. Supplement: (Second edition). P.1-352.

Ho J.-S. 1984. New family of poecilostomatoid copepods (Spiophanicolidae) parasitic on polychaetes from Southern California, with a phylogenetic analysis of nereicoliform families // Journal of Crustacean Biology. Vol.4. No.1. P.134-146.

Ho J.-S., Kim I.-H. 1990. Hemicyclops ctenidis, a new poecilostomatoid copepod (Clausidiidae) associated with a polychaete in Korea // Korean Journal of Zoology. Vol.33. No.2. P.231-237.

Ho J.-S., Kim I.-H. 2003. New clausiid copepods (Poecilostomatoida) associated with polychaetes of Korea, with cladistic analysis of the family Clausiidae // Journal of Crustacean Biology. Vol.23. No.3. P.568-581.

Humes A.G. 1994. How many copepods? // Ecology and Morphology of Copepods. F.D. Ferrari and B.P. Bradley (eds.). Hydrobiologia. Vol.292/293. No.1. P.1-7.

Kim I.-H. 1998. Illustrated Encyclopedia of Fauna and Flora of Korea. Vol 38. Cirripedia, Symbiotic Copepoda, and Pycnogonida. Seoul: Ministry of Education of Korea. 1038 p.

Kim I.-H. 2000. Poecilostomatoid copepods from an intertidal mud flat in the Yellow Sea // Journal of Natural History. Vol.34. No.3. P.367-432.

Kim I.-H. 2001a. A new species of Clausia (Copepoda, Poecilostomatoida, Clausiidae) associated with the polychaete Arenicola brasilliensis Nonata in Korea // Hydrobiologia. Vol.452. No.1/3. P.217-223.

Kim I.-H. 2001b. Foliomolgus cucullus, a new genus and species of Clausidiidae (Crustacea: Copepoda: Poecilostomatoida) associated with a polychaete in Korea // Proceedings of the Biological Society of Washington. Vol.114. No.3. P.660-666.

Kim I.-H. 2001c. A new genus and two new species of Copepoda (Poecilostomatoida, Sabelliphilidae) associated with the tubicolous polychaetes in the Yellow Sea // Korean Journal of Biological Sciences. Vol.5. No.1. P.1-9.

Kim I.-H., Ho J.-S. 1992. Copepodid stages of Hemicyclops ctenidis Ho \& Kim, 1990 (Clausidiidae), a poecilostomatoid copepod associated with a polychaete// Journal of Crustacean Biology. Vol.12. No.4. P.631-646.

Radashevsky V.I. 1993. Revision of the genus Polydora and related genera from the North West Pacific (Polychaeta: Spionidae) // Publications of the Seto Marine Biological Laboratory. Vol.36. No.1/2. P.160.

Radashevsky V.I. 1996. Morphology, ecology and asexual reproduction of a new Polydorella species (Polychaeta: Spionidae) from the South China Sea // Bulletin of 
Marine Science. Vol.58. No.3. P.684-693.

Williams J.D. 2004. Reproduction and morphology of

Polydorella (Polychaeta: Spionidae), including the description of a new species from the Philippines //
Journal of Natural History. Vol.38. No.11. P.13391458.

Responsible editors Frank D. Ferrari, V.N. Ivanenko 